\title{
Differential gene expression between human schwannoma and control Schwann cells
}

\author{
C. O. Hanemann*, B. Bartelt-Kirbach†, R. Diebold†, K. Kämpchen†, S. Langmesserł and T. Utermark§ \\ *Clinical Neurobiology, Peninsula Medical School, Peymouth, UK, †Center for Clinical Research, Department of Heurology, \\ University Ulm, Ulm, Germany, ‡Institut de Biochimie, Université de Fribourg, Fribourg, Switzerland, and §Department of \\ Cancer Biology, Dana-Farber Cancer Institute, Boston, MA, USA
}

The NF2 gene encodes the tumour suppressor protein merlin. The mutation of a single allele of this gene causes the autosomal dominantly inherited disease neurofibromatosis type 2 (NF2), which is characterized mainly by vestibular schwannoma carrying a second hit mutation. Complete lack of merlin is also found in spontaneous schwannomas and meningiomas. As the events leading to schwannoma development are largely unknown we investigated the differences in gene expression between schwannoma cells from NF2 patients and normal human primary Schwann cells by cDNA array analysis. We iden- tified 41 genes whose expression levels differed by more than factor 2. Most of these clones were corroborated by real-time reverse transcription polymerase chain reaction analysis. By this method a total of seven genes with increased and seven genes with decreased mRNA levels in schwannoma compared with normal Schwann cells could be identified. Regulated clones, some of which not been described in Schwann cells earlier, included matrix metalloproteinase's, growth factors, growth factor receptors and tyrosine kinases.

Keywords: cells cultured, gene expression, human, neurofibromatosis, Schwann cells, schwannoma

\section{Introduction}

The NF2 gene is located on chromosome 22q12.2 and codes for the tumour suppressor protein merlin/schwannomin [1,2]. Merlin belongs to the protein 4.1 super family and shows high homology to the ERM (ezrin, radixin, moesin) proteins of cytoskeleton-cell membrane linkers. A germ line mutation in one allele of the NF2 gene causes the autosomal dominantly inherited cancer predisposition syndrome neurofibromatosis type 2 (NF2). This syndrome is characterized by bilateral vestibular schwannomas and

Correspondence: C. Oliver Hanemann, Clinical Neurobiology, Institute of Biomedical and Clinical Science, Peninsula Medical School, Tamar Science Park, Research Way, Plymouth PL6 8BU, UK. Tel: +44 1752437418; Fax: +44 1752517846; E-mail: oliver.hanemann@pms.ac.uk in addition, benign tumours of the nervous system such as meningiomas and ependymoma's are also common to this disease. Bi-allelic mutations of the NF2 gene have been identified in not only all of the NF2-related tumours, but also in $100 \%$ of spontaneous schwannomas and 50-60\% of spontaneous meningiomas [3,4]. Consequently, Merlin is undetectable in the tumour samples [5-7]. Recent findings in primary human Schwann and schwannoma cells indicate that loss of merlin impairs contact-dependent growth arrest as well as the formation of stable cadherincontaining cell-cell junctions [8] (Utermark et al. submitted) and causes alterations in the adhesion to the extra cellular matrix [9].

Classical Merlin knockout mice develop various kinds of tumours, most of them highly malignant, but no schwannomas [10]. 
Up to date several interaction partners of merlin have been identified, mostly using either mouse or rat model systems. Among those binding partners betaII-spectrin [11], CD44 [12], magicin [13], HRS (hepatocyte growth factor-regulated tyrosine kinase substrate) [14], paxillin [15], NHERF (EPB-50) [16] and PIKE-L [17] to merlin were also found in human cell line settings.

Concerning cell-type specificity the association of merlin with CD44, betaII-spectrin, HRS and paxillin was shown in rat Schwann or schwannoma cells. We were unable to detect the expression of, for example, magican in human Schwann cells (Hanemann et al. unpubl. data). It is, however, likely that interaction partners of merlin will be identified in human Schwann cells in the future.

Merlin has been demonstrated to be involved in intracellular signalling in different cell types. Merlin is involved in the Rac/Pak signalling pathway [18-22]. Rac1 activation hardly detectable in merlin -/- mouse fibroblast [23] is clearly upregulated in primary human schwannoma cells [19]. Also, merlin increases the p53 stability by inhibiting the Mdm2-mediated degradation of p53 [24].

In order to identify genes involved in schwannoma development, we performed cDNA array analyses and subsequent real-time reverse transcription polymerase chain reaction (RT-PCR) on primary cell cultures of human NF2 schwannomas, presenting a defined genotype, compared with human Schwann cells of healthy donors. By means of this approach we were able to identify a number of differentially regulated genes, some of which so far were not known to be expressed in human Schwann cells.

\section{Materials and methods}

\section{Cell culture}

Normal human Schwann and schwannoma cells were isolated and cultured as previously described [25,26]. Peripheral nerves were obtained from surgical patients not carrying any disease predisposing to a peripheral neuropathy after informed consent. Schwannoma were kindly provided by NF2 patients after informed consent. Diagnosis of NF2 was based on clinical criteria defined by the NIH Consensus Conference on Neurofibromatosis [27]. At the time of RNA extraction cell cultures were intended to be grown to an equal confluency of about $80 \%$.

\section{RNA extraction}

Total RNA was extracted from cell cultures homogenized by QiaShredder (Qiagen, Hilden, Germany) using the method described by Chomczynski and Sacchi [28], followed by DNase I treatment. RNA for real-time PCR analysis was also extracted using the RNeasy spin columns (Qiagen, Hilden, Germany) according to the manufacturers instructions with DNase I treatment on the columns. RNA integrity was checked on a $0.8 \%$ agarose gel stained with ethidium bromide.

\section{CDNA array analysis}

Hybridization of cDNA to the Atlas Human 1.2 Array (BD Biosciences, San Jose, CA, USA) was performed according to the manufacturer's instructions with the following exceptions. For probe synthesis with the Clontech Probe Synthesis Kit, MMLV reverse transcriptase was replaced by SuperScript ${ }^{\mathrm{TM}}$ (Invitrogen, Carlsbad, CA, USA). Probes were purified by ChromaSpin columns (BD Biosciences, San Jose, CA, USA) and [32P]dATP labelling efficiency was measured by a beta counter. Hybridized array membranes were exposed to a phosphor intensifying screen (Molecular Dynamics, Freiburg, Germany) and scanned at three time points (days 1, 3 and 8). Data analysis was carried out using the ImageQuant software (Amersham Pharmacia Biotech, Freiburg, Germany). The signal intensity between arrays was normalized against the housekeeping genes on the respective array as well as total array counts as suggested by the manufacturer. We used two different established methods of normalization to add additional security. For significance, a doubling of the signal intensity was requested. The experiment was repeated twice, using RNA of different normal human Schwann and schwannoma cells.

\section{Real-time RT-PCR analysis}

cDNA was synthesized with the First strand cDNA synthesis kit for RT-PCR (AMV) (Roche Applied Science, Mannheim, Germany) using a fixed volume of the eluted RNA $(8.2 \mu \mathrm{l})$ and random hexamer primers.

For real-time PCR analysis, a LightCycler (Roche Applied Science, Mannheim) with software LightCycler 3 Run, version 5.32, and LightCycler 3 Data Analysis, version 3.5.28, was applied using SYBR green (LightCycler 
DNA Master SYBR Green I, Roche Applied Science, Mannheim, Germany) or the QuantiTect SYBR Green PCR Kit (Qiagen, Hilden, Germany), according to the respective manufacturers instructions. After the LightCycler run, the real-time PCR products were checked for unwanted by-products on a $2 \%$ agarose gel stained with ethidium bromide, and runs with by-products were optimized until only the wanted product was amplified.

Primers and PCR conditions used are listed in Table 1.
For the relative quantification of the cDNA amounts we used the standard curve method and normalization to the housekeeping gene HPRT (hypoxanthine guanine phosphoribosyltransferase). For each primer pair serial dilutions of the cDNA ranging from 1:10, 1:25 and 1:501:100 were performed. The Crossing Points for the individual sample are automatically determined by the Second Derivate Maximum Method (Roche Applied Science). Using the linear regression line the relative concentration

Table 1. Primer sequences, product length and annealing temperature used for real-time polymerase chain reaction

\begin{tabular}{|c|c|c|c|c|}
\hline Gene & Upstream primer & Downstream primer & Size (bp) & Annealing $\left({ }^{\circ} \mathrm{C}\right)$ \\
\hline APP & $5^{\prime}$-ctcccgctggtactttgatgtg- $3^{\prime}$ & $5^{\prime}$-gggcaagaggttcctgggtagt- $3^{\prime}$ & 164 & 60 \\
\hline CBL-B & $5^{\prime}$-ccacgattatgggctcagtt- $3^{\prime}$ & $5^{\prime}$-gaaatgggctccacttttca-3' & 178 & 60 \\
\hline CCND1 & $5^{\prime}$-ccgtccatgcggaagatc- $3^{\prime}$ & $5^{\prime}$-atggccagcgggaagac- $3^{\prime}$ & 86 & 60 \\
\hline CD19 (Paradisi et al.) & $5^{\prime}$-ctccacactctggctgtcct- $3^{\prime}$ & $5^{\prime}$-cagcagccagtgccatagta-3' & 277 & 55 \\
\hline CDKN1A & $5^{\prime}$-caggggacagcagaggaaga- $3^{\prime}$ & $5^{\prime}$-gcttcctgtgggcggatta- $3^{\prime}$ & 201 & 60 \\
\hline CRHR1 & $5^{\prime}$-agccatcgtgctcacctact- $3^{\prime}$ & $5^{\prime}$-ggggccctggtagatgtagt- $3^{\prime}$ & 181 & 60 \\
\hline CTNNA1 & $5^{\prime}$-gctgctctccaacacagtcac- $3^{\prime}$ & $5^{\prime}$-cgctcgtcctgcttctg-3' & 235 & 55 \\
\hline FLT1 & $5^{\prime}$-ctttaaccttgaacacagctca $3^{\prime}$ & $5^{\prime}$-gtaacagtgatgttaggtgacgtaa- $3^{\prime}$ & 231 & 60 \\
\hline GRLF1 & $5^{\prime}$-aaaatcaacgaccgggagca-3' & $5^{\prime}$-gggccagaagcagatggaga-3' & 171 & 60 \\
\hline GRO2 & $5^{\prime}$-cacactcaagaatgggcaga- $3^{\prime}$ & $5^{\prime}$-aaacacattaggcgcaatcc-3' & 217 & 60 \\
\hline HMGA & $5^{\prime}$-tgggttccatttttcctctg-3' & $5^{\prime}$-aacaggaggcaatgaggatg-3' & 133 & 60 \\
\hline IGFBP1 & $5^{\prime}$-ccctgaaagcccagagagca- $3^{\prime}$ & $5^{\prime}$-ggcagggctccttccatttt-3' & 170 & 60 \\
\hline IL11 & $5^{\prime}$-gcctgtggggacatgaact- $3^{\prime}$ & $5^{\prime}$-gcagggaatccaggttgtgg- $3^{\prime}$ & 239 & 60 \\
\hline \multirow[t]{2}{*}{ INHA } & up $15^{\prime}$-tctgagcccgaggaagagga- $3^{\prime}$ & $5^{\prime}$-gctgcgtgtatgctgggatg-3' & 156 & 55 \\
\hline & up2 $5^{\prime}$-gaaggtggggaccctggagt- $3^{\prime}$ & $5^{\prime}$-gctgcgtgtatgctgggatg-3' & 225 & 55 \\
\hline ITGA6 & $5^{\prime}$-cagttgagttgtgttgccaa-3' & $5^{\prime}$-gaaggtttagcaactcccg-3' & 250 & 55 \\
\hline ITGB1 & $5^{\prime}$-gtggttgctggaattgttctta-3' & $5^{\prime}$-agtgttgtgggatttgcac- $3^{\prime}$ & 219 & 55 \\
\hline ITGB4 & $5^{\prime}$-atagagtcccaggatggagga- $3^{\prime}$ & $5^{\prime}$-gtggtggagatgctgctgta- $3^{\prime}$ & 97 & 55 \\
\hline JNK2 & $5^{\prime}$-cgccactccttctcagtcttc- $3^{\prime}$ & $5^{\prime}$-ccatcaactcccaagcatttc- $3^{\prime}$ & 200 & 55 \\
\hline MAG & $5^{\prime}$-tgccatcgtctgctacattaccc- $3^{\prime}$ & $5^{\prime}$-caggcgcctctcgctctcg-3' & 151 & 60 \\
\hline MAP2K3 & $5^{\prime}$-gaccttcatcaccattggag-3' & $5^{\prime}$-cgtagaaggtgacagtgtag-3' & 232 & 60 \\
\hline MAP3K11 & $5^{\prime}$-gctgctgtgggaactgctga- $3^{\prime}$ & $5^{\prime}$-ctgcaggatggaggcgaagt- $3^{\prime}$ & 193 & 60 \\
\hline $\mathrm{MCP} 1$ & $5^{\prime}$-gtgttcaagtcttcggagtt- $3^{\prime}$ & $5^{\prime}$-caataggaagatctcagtgc- $3^{\prime}$ & 187 & 60 \\
\hline MMP11 & $5^{\prime}$-aggtactggcatggggacga- $3^{\prime}$ & $5^{\prime}$-gccttggctgctgttgtgtg- $3^{\prime}$ & 212 & 60 \\
\hline MMP14 & $5^{\prime}$-cactgcctacgagaggaagg-3' & $5^{\prime}$-ttggggtactcgctatccac- $3^{\prime}$ & 246 & 60 \\
\hline MMP17 & $5^{\prime}$-ctccaaggccgaccataacg-3' & $5^{\prime}$-cgtggacagccactgcaaac-3' & 179 & 60 \\
\hline NR2F1 (Moré et al. 2003) & $5^{\prime}$-gctgcctcaaagccatcgtg-3' & $5^{\prime}$-aaggtctaggagcactggatgga- $3^{\prime}$ & 318 & 62 \\
\hline PDGFA & $5^{\prime}$-gctgctgcaacacgagcagt- $3^{\prime}$ & $5^{\prime}$-ccggattcaggcttgtggtc- $3^{\prime}$ & 168 & 60 \\
\hline PEP1 & $5^{\prime}$-attctccaaccaatgatgtgc- $3^{\prime}$ & $5^{\prime}$-ggattggagagacagcgaag-3' & 283 & 55 \\
\hline PGF & $5^{\prime}$-gttcagcccatcctgtgtct- $3^{\prime}$ & $5^{\prime}$-cttcatcttctcccgcagag-3' & 199 & 60 \\
\hline PRNP & $5^{\prime}$-tccgagccagtcgctgacag-3' & $5^{\prime}$-cctgaggtgggtagcggttg-3' & 225 & 60 \\
\hline PTMA & $5^{\prime}$-cgggaatgctaatgaggaaa- $3^{\prime}$ & $5^{\prime}$-tcggtcttctgcttcttggt- $3^{\prime}$ & 213 & 60 \\
\hline P75 & $5^{\prime}$-gtgggacagagtctgggtgt- $3^{\prime}$ & $5^{\prime}$-aaggaggggaggtgatagga- $3^{\prime}$ & 199 & 63 \\
\hline RAC1 & $5^{\prime}$-gccgattgccgatgtgtt- $3^{\prime}$ & $5^{\prime}$-ctcggatcgcttcgtcaaa- $3^{\prime}$ & 307 & 55 \\
\hline SLC6A6 & $5^{\prime}$-gctgagcttgtcccctggaa- $3^{\prime}$ & $5^{\prime}$-aggagcatggcgaatggaaa-3' & 165 & 60 \\
\hline TIE1 & $5^{\prime}$-tggcatggagtgcactgtga-3' & $5^{\prime}$-aatggccttggtggacagga- $3^{\prime}$ & 189 & 60 \\
\hline TIMP & $5^{\prime}$-cacccacagacggccttct-3' & $5^{\prime}$-aggcttggaaccctttatacatctt- $3^{\prime}$ & 136 & 60 \\
\hline TNK1 & $5^{\prime}$-cctccagggecctctactcc- $3^{\prime}$ & $5^{\prime}$-tctgtggcatccctcacacaa-3' & 135 & 55 \\
\hline VEGF & $5^{\prime}$-cacccatggcagaaggagga- $3^{\prime}$ & $5^{\prime}$-actccaggccetcgtcattg- $3^{\prime}$ & 201 & 60 \\
\hline ZNF161 & $5^{\prime}$-tcgacacaagctctcccattca-3' & $5^{\prime}$-ggtcaggccttgagaagccttt- $3^{\prime}$ & 167 & 60 \\
\hline HPRT (Erovic et al. 2003) & $5^{\prime}$-gccagactttgttggatttg- $3^{\prime}$ & $5^{\prime}$-ctctcatcttaggctttgtattttg-3' & 141 & $55-62$ \\
\hline TBP (Bieche et al. 1999) & $5^{\prime}$-cacgaaccacggcactgatt- $3^{\prime}$ & $5^{\prime}$-ttttcttgctgccagtctggac- $3^{\prime}$ & 89 & $55-62$ \\
\hline G6PDH (Radonic et al. 2004) & $5^{\prime}$-atcgaccactacctgggcaa-3' & $5^{\prime}$-ttctgcatcacgtcccgga- $3^{\prime}$ & 191 & $55-62$ \\
\hline
\end{tabular}


of the unknown sample is calculated following the normalization with the regression line of the housekeeping gene. As a second method we used the approach described by Ramakers et al. [29], which determines the PCR efficiency from the increase of absolute fluorescence within the window of linearity of the PCR reaction by linear regression. The amount of starting template then follows from the intercept of this linear regression line. The computer program called LinRegPCR for easy use of the method is available upon request, email to bioinfo@amc.uva.nl. For normalization of our data to three housekeeping genes, we used the GeNorm VBA applet for MS Excel [30] (available at http://medgen.ugent.be/ $\% 7$ Ejvdesomp/genorm/). It determines the most stable housekeeping gene in a given set of four tested housekeeping genes. The three most stable ones are then selected for sample normalization. For this, the applet calculates a normalization factor for each sample based on the geometric mean of the three housekeeping genes. The three housekeeping genes used were HPRT (hypoxanthine guanine phosphoribosyltransferase), TBP (TATA-box binding protein) and G6PDH (glucose-6-phosphate dehydrogenase).

\section{Western blot}

Cell pellets were lysed using $100 \mu \mathrm{l}$ of denaturing lysis buffer [1\% TritonX-100; $20 \mathrm{mM}$ Tris-HCl (pH 7.5); $150 \mathrm{mM} \mathrm{NaCl} ; 1 \mathrm{mM} \mathrm{MgCl} 2 ; 2$ mM EDTA; $10 \%$ Glycerol; $0.1 \%$ SDS; $1 \%$ Sodium deoxycholate; 1:500 small peptide inhibitor mix (Sigma, St. Louis, MO, USA); 1:100 $100 \mathrm{mM}$ PMSF stock (Sigma) (in 100\% ethanol) per $4 \times 10^{5}$ cells]. Protein concentrations were determined with a detergent compatible protein assay (Biorad, Hercules, CA, USA) and proteins were separated by SDS-Page on $8 \%$ polyacrylamide gels. Coomassie blue staining (Biorad) and subsequent analysis of the relative lane intensities by use of the GelPro Analyser software (Media Cybernetics, Workingham, UK) was used to allow more accurate loading ratios between a particular pair of normal Schwann cell and schwannoma cell lysate. Proteins were transferred to either nitrocellulose (Hybond ECL, Amersham Pharmacia Biotech), or polyvinylidene fluoride (Immobilon P 1500, Millipore, Billerica, MA, USA) membrane by wet transfer. Primary antibodies used were polyclonal anti-RhoGDI (1:500; Santa Cruz, Santa Cruz, CA, USA, A20), polyclonal anti-nerve growth factor (NGF) receptor (1:1000; Sigma N3908). Overnight incubation was followed by incubation with corresponding secondary antibody marked with horseradishperoxidase (HRP) and ECL detection. After revelation, membranes were subjected to a Colloidal Gold Total Protein staining (Biorad) according to the manufacturer's protocol. Lane band densities were compared between schwannoma and Schwann cell total protein lysates, thus ascertaining not only equal loading, but also equivalent transfer of the proteins onto the membrane.

Thus, in total controls of equal loading and transfer were assured at four different levels: (i) equivalent number of cells per volume of lysis buffer; (ii) protein assay based on Lowry; (iii) Coomassie blue stain on gels; and (iv) colloidal gold stain of membrane.

\section{Results cDNA array analysis}

The Atlas Human 1.2 cDNA Array was used to determine differential expression between primary human schwannoma and normal Schwann cells. Within the total of 1176 genes dotted on the cDNA array, 41 were found to be either up- or downregulated by a factor of $\geq 2$ (Table 2 , gene bank accession numbers are given in italics). House keeping genes on the array for normalization were chosen as it has been published numerous times that they are not regulated. However, we also used total array signal for normalization in addition as suggested as an alternative by the manufacturer. Thirty genes were regulated to similar extent using both methods for normalization, 11 genes were regulated $\geq 2$ using one of the normalization methods. All genes regulated by applying combined methods (total array signal and housekeeping signal) of normalization were certainly also regulated also using just one method of normalization.

\section{Real-time RT-PCR analysis}

Thirty-six of the 41 genes identified by array analysis were further investigated by real-time RT-PCR analysis with at least three different pairs of schwannoma/normal Schwann cell cDNA. The genes omitted from real-time PCR analysis were CD44 which has earlier been investigated by Sherman et al. [31], HSP27 which has been investigated by Utermark et al. [32], GATA2 (GATA-binding protein 2), SLC5A2 (solute carrier family 5 , member 2) and FLT1 [vascular endothelial growth factor (VEGF) receptor 1] which gave no reproducible RT-PCR results.

Table 3 summarizes the results of the real-time RT-PCR analysis. Fourteen genes of this set showed a reliable 
Table 2. Genes with differential regulation between Schwann and schwannoma cells as found by array analysis

\begin{tabular}{|c|c|}
\hline Increased & Decreased \\
\hline Alpha1 catenin (CTNNA1) D13866; L23805 & $\begin{array}{l}\text { CAS-BR-M murine ecotropic retroviral transforming sequence B } \\
\text { (CBL-B) U26710 }\end{array}$ \\
\hline Alzheimer's disease amyloid A4 protein precursor (APP) Y00264 & c-jun N-terminal kinase 2 (JNK2) L31951 \\
\hline B-lymphocyte CD19 antigen precursor (CD19) M21097 & Interleukin-11 (IL-11) M57765 \\
\hline CD44 antigen haematopoietic form precursor (CD44) M59040 & Low-affinity nerve growth factor receptor (NGFR) M14764 \\
\hline $\begin{array}{l}\text { Cortiocoropin releasing factor receptor } 1 \text { precursor (CRHR1) } \\
\quad \text { X72304 }\end{array}$ & $\begin{array}{l}\text { Macrophage inflammatory protein } 2 \text { alpha (MIP2-alpha, GRO2) } \\
\quad \text { 553779 }\end{array}$ \\
\hline Cyclin-dependent kinase inhibitor 1 (CDKNA1A) U09579; L25610 & Matrix metalloproteinase 11 (MMP11) X5776 \\
\hline Endothelial transcription factor GATA2 M68891 & Matrix melalloproteinase 14 precursor (MMP14) D25612; X83535 \\
\hline Glucocorticoid receptor DNA binding factor 1 (GRFL1) M73033 & Myelin-associated glycoprotein precursor (MAG) M29273 \\
\hline 27-kDa heat-shock protein 27-kDaA (HSP27) X54079 & Placenta growth factors $1+2$ (PGF) X54936 \\
\hline Integrin alpha 6 precursor (ITGA6) M35198; J05522 & Tyrosine kinase receptor tie-1 precursor (TIE1) X60957; S89716 \\
\hline Integrin beta 1 (ITGB1) X07979 & High mobility group protein (HMG-I) M23619 \\
\hline Integrin beta 4 (ITGB4) X53587; X51841 & Matrix metalloproteinase 17 (MMP17) X89576 \\
\hline Major prion protein precursor (PRP) M13667 & Metalloproteinase inhibitor 1 precursor (TIMP1) X03124 \\
\hline $\begin{array}{l}\text { Platelet-derived growth factor A subunit precursor (PDGFA) } \\
\quad \text { X06374 }\end{array}$ & $\begin{array}{l}\text { Dual specificity mitogen-activated protein kinase kinase } 3 \text { (MAP2K3) } \\
\text { L36719 }\end{array}$ \\
\hline Prothymosin alpha (PTMA) M26708 & Inhibin alpha subunit precursor (INHA) M13981 \\
\hline Putative transcription activator DB1 (ZNF161) D28118 & Protein kinase MLK-3 (MAP3K11) L32976 \\
\hline $\begin{array}{l}\text { Ras-related C3 botulinum toxin substrate 1; p21-rac1(RAC1) } \\
\quad \text { M29870; M31467 }\end{array}$ & $\begin{array}{l}\text { Vascular endothelial growth factor receptor } 1 \text { (FLT1) X51602; } \\
\text { U01134 }\end{array}$ \\
\hline \multicolumn{2}{|l|}{$\begin{array}{l}\text { Sodium- and chloride-dependent taurine transporter (SLC6A6) } \\
\quad \text { Z18956 }\end{array}$} \\
\hline \multicolumn{2}{|l|}{ Tyrosine kinase tnk1 (TNK1) U43408 } \\
\hline \multicolumn{2}{|l|}{$\begin{array}{l}\text { Vascular endothelial growth factor precursor (VEGF) M32977; } \\
\text { M27281 }\end{array}$} \\
\hline \multicolumn{2}{|l|}{ G1/S-specific cyclin D1 (CCND1) X59798; M64349 } \\
\hline \multicolumn{2}{|l|}{ ETS oncogene (PEP1) L16464 } \\
\hline \multicolumn{2}{|l|}{ Insulin-like growth factor binding protein 1 (IGFBP1) M31145 } \\
\hline Monocyte chemotactic protein 1 precursor (MCP1) M24545 & \\
\hline
\end{tabular}

regulation ( $\geq 2$-fold), seven of which were upregulated in schwannoma cells, seven downregulated. Two were found to be expressed at a level too low for reliable quantification. The regulated cDNAs include transmembrane proteins (integrins $\alpha 6, \beta 1$ and $\beta 4$ ), proteins involved in the remodelling of the extra cellular matrix (matrix metalloproteinase's MMP11 and MMP14), growth factors, growth factor receptors and associated proteins [placental growth factor (PGF), VEGF, p75 low-affinity nerve growth facto receptor, insulin growth factor binding protein 1 (IGFBP1)], two tyrosine kinases (TIE1, TNK1), a cytokine (interleukin IL11), myelin-associated glycoprotein (MAG) and prion protein (PRNP).

Integrins $\alpha 6, \beta 1$ and $\beta 4$, the small GTPase Rac 1 and Jun - kinase 2 were chosen for detailed analysis of protein expression, kinase activity assays, immunocytochemistry, immunohistochemistry and functional assays in separate studies [9,19]. Because of the established role of merlin in the Rac signalling pathway we further analysed protein expression of RhoGDI, which regulates small GTPases. As human schwannoma cells show altered migration properties [32] and as low-affinity NGF receptor is involved in Schwann cell migration and survival [33], we also analysed p75 low-affinity NGF receptor expression at protein level in primary human schwannoma and Schwann cells by Western Blot. RhoGDI and p75 low-affinity NGF receptor showed no differential expression in Schwann and schwannoma cells (Figure 1). These protein expression data are in line with RNA data by cDNA array (RhoGDI data are not shown in Table 2 as they were not differentially expressed) and RT-PCR.

\section{Discussion}

In this work we aimed to identify differences in the mRNA expression levels in primary Schwann cells derived either from human schwannoma tumour biopsies or normal nerve which might be involved in the progression of 
Table 3. Genes with differential regulation between Schwann and schwannoma cells as found by real-time polymerase chain reaction

\begin{tabular}{|c|c|c|}
\hline Gene & Mean \pm SEM & Regulation in schwannoma \\
\hline APP & $0.74 \pm 0$ & None \\
\hline CBL-B & $0.87 \pm 0.15$ & None \\
\hline CCND1 & $1.72 \pm 0.31$ & None \\
\hline CD19 & NA & NA \\
\hline CDKN1A & $1.55 \pm 0.22$ & None \\
\hline CTNNA1 & $1.28 \pm 0.35$ & None \\
\hline GRLF1 & $0.7 \pm 0.06$ & None \\
\hline GRO2 & $1.38 \pm 0.31$ & None \\
\hline HMGA & $1.01 \pm 0.20$ & None \\
\hline IGFBP1 & $25.26 \pm 8.20$ & Up \\
\hline IL11 & $0.31 \pm 0.06$ & Down \\
\hline INHA & $1.63 \pm 0.27$ & None \\
\hline ITGA6 & $8.54 \pm 1.13$ & Up \\
\hline ITGB1 & $9.36 \pm 4.08$ & Up \\
\hline ITGB4 & $185.17 \pm 85.08$ & Up \\
\hline JNK2 & $1.24 \pm 0.12$ & None \\
\hline MAG & $0.18 \pm 0.02$ & Down \\
\hline MAP2K3 & $0.29 \pm 0.17$ & Down \\
\hline MAP3K11 & $0.64 \pm 0.10$ & None \\
\hline MCP1 & $1.62 \pm 0.17$ & None \\
\hline MMP11 & $0.27 \pm 0.05$ & Down \\
\hline MMP14 & $0.32 \pm 0.08$ & Down \\
\hline MMP17 & $0.98 \pm 0.16$ & None \\
\hline PDGFA & $1.55 \pm 0.06$ & None \\
\hline PEP1 & $1.84 \pm 0.28$ & None \\
\hline PGF & $0.53 \pm 0.11$ & Down \\
\hline PRP & $2.84 \pm 0.25$ & Up \\
\hline PTMA & $1.29 \pm 0.30$ & None \\
\hline P75 & $0.65 \pm 0.09$ & None \\
\hline RAC1 & $1.66 \pm 0.30$ & None \\
\hline SLC6A6 & $1.09 \pm 0.15$ & None \\
\hline TIE1 & $0.33 \pm 0.04$ & Down \\
\hline TIMP1 & $0.89 \pm 0.13$ & None \\
\hline TNK1 & $2.1 \pm 0.10$ & Up \\
\hline VEGF & $3.41 \pm 1.05$ & Up \\
\hline ZNF161 & $1 \pm 0.15$ & None \\
\hline
\end{tabular}

NA, not available.

Schwann to schwannoma cells. Using cDNA array hybridization followed by real-time RT-PCR confirmation, we found 13 genes to be differentially expressed in schwannoma cells compared with Schwann cells. Most of them have not yet been shown to be associated with schwannoma, though are known to play a role in the progression of other tumours.

A similar study was conducted by Welling et al. [34] on vestibular schwannoma vs. peripheral nerve tissue. They found 42 genes to be upregulated in the majority of tumours they investigated. Eight genes were significantly downregulated. Importantly there is no overlap in the findings between the study by Welling and our own data

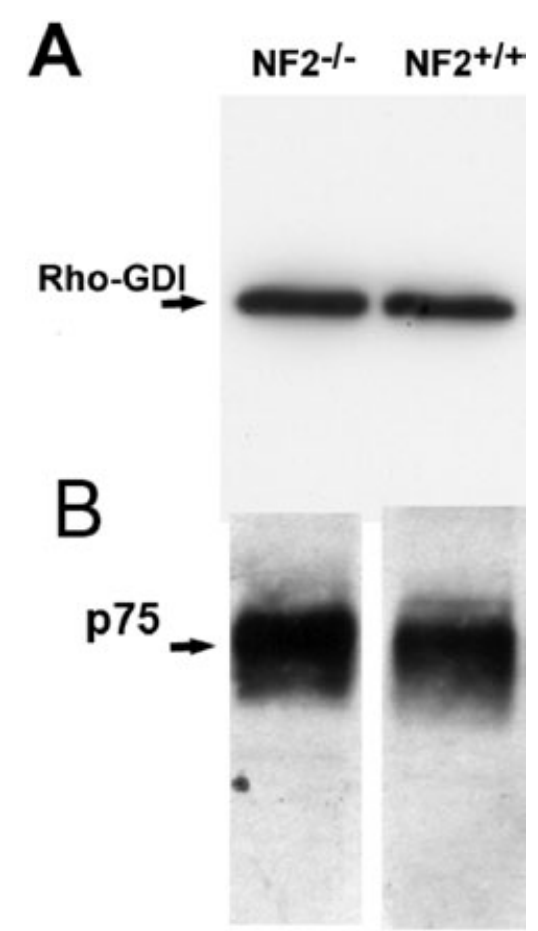

Figure 1. Rho-GDI and p75 expression in Schwann and schwannoma cells. Western blot analysis of total cell lysates $\left(\mathrm{NF}^{-/-}\right.$ = schwannoma cells; $\mathrm{NF}^{+/+}=$Schwann cells) after SDS-page, probing for Rho-GDI (A) and p75 (B).

presented here. However, as they also state in their discussion, their use of vestibular nerve adjacent to the tumour as a control is not ideal. Furthermore normal nerve tissue consists of myelinating Schwann cells attached to axons whereas in schwannoma nonmyelinating Schwann cells dominate. Thus, Schwann cell proteins regulated by axon contact are upregulated in the experimental design of that group. We chose to investigate cultured primary cells in order to have comparable Schwann cell differentiation stimuli for both cell types. Using almost pure standardized cell cultures, however, also has its drawbacks, as cells are known to undergo changes in their expression profiles in vitro. However, among the differentially expressed genes identified by us, the genes encoding for the integrin chains $\alpha 6, \beta 1$ and $\beta 4$ have been investigated in great detail by our group. The mRNA over expression of those in schwannoma cells could not only be clearly detected at protein level using different methods as well as in tissue sections, but did also correlate with increased adhesion to extra cellular matrix [9]. Thus, these findings strongly indicate that our experimental set-up is valuable.

Genes for which differential regulation was discovered in our cDNA array analysis and which were not known to 
be regulated or expressed in Schwann cells are discussed in more detail below.

We found MAG is downregulated in human schwannoma cells. MAG is a membrane protein involved in the process of myelination. It is expressed in differentiated Schwann cells. Rat schwannoma cell lines express mainly the short isoform S-MAG. Three rat schwannoma cell lines show an inverse correlation of MAG expression and proliferation [35]. This fits for our human schwannoma cells as they present higher proliferation rates compared with their normal counterparts [36] and MAG expression was found to be downregulated.

The prion protein precursor gene (PRNP) coding for the prion protein $(\mathrm{PrP})$ gene is upregulated in human schwannoma cells. It is a ubiquitous glycoprotein expressed strongly in neurones and its expression in mouse Schwann cells has been described by Ford et al. [37]. As a plasma membrane protein PrP is involved with copper uptake, protection against oxidative stress, cell adhesion, differentiation, signalling and survival in the central nervous system. Interestingly PRNP has been found to be over expressed in a TNF-resistant human breast carcinoma cell line [38], thus indicating a potential role in other tumours.

The matrix metalloproteinase's 11 (MMP11) and 14 (MMP14) are both downregulated in schwannoma cells. Matrix metalloproteinase's are involved in the remodelling of the extra cellular matrix and overexpression of MMPs is often correlated with tumour progression such as invasive tumour growth. MMP14 but not MMP11 has been described in the peripheral nervous system [39]. It is of interest that plexiform neurofibromas express fewer MMP-3 and MMP-1 than normal human Schwann cells [40]. To understand the role of MMP in schwannomas other MMP's and MMP activity need to be analysed.

Interleukin 11 (IL11), downregulated in schwannoma cells, is an anti-inflammatory cytokine with multiple biological activities. It has been shown to stimulate proliferation of human myeloma cell lines. Other than that, no role in tumourigenesis has yet been described for this protein. Interestingly, in the setting of peripheral nerve injury IL11 expression is known to be increased followed by an immediate restoration of the basal levels [41], suggesting a distinct function in nerve regeneration and Schwann cell differentiation.

The gene for PGF is also downregulated in human schwannoma cells. PGF expression has not been described in Schwann cells before. PGF belongs to the family of vas- cular endothelial growth factors (VEGF) and its over expression has accordingly been linked to tumour angiogenesis [42]. The regulation we found is difficult to interpret as schwannoma cell cultures are no model for angiogenesis and schwannomas are not highly vascularized. Thus, other roles of PGF, for example, affecting monocyte activation, remain to be investigated in schwannomas.

On the other hand, VEGF itself is upregulated in human schwannoma cells, pointing to a different role of the two proangiogenic factors. In addition to playing a role in angiogenesis also in peripheral nerves [43], VEGF influences differentiation of different cell types, which includes acting as a Schwann cell mitogen [44]. VEGF is upregulated by hypoxia, which does not play a role in a cell culture system. However, not all isoform's of VEGF are regulated by hypoxia [45]. Our primer pair for quantitative RT-PCR is not able to distinguish between the different isoform's. Interestingly VEGF is expressed in schwannomas and one study found a positive correlation of VEGF measured by ELISA and tumour growth measured by twodimensional MRI measurement [46].

The insulin-like growth factor binding protein 1 (IGFBP1) is strongly upregulated in schwannoma cells. IGFBP-1 binds to the insulin-like growth factor 1 (IGF-1) and regulates its availability increasing or decreasing it depending on the physiological context [47]. IGF-1 has a role in cell differentiation as wells as acts a mitogen for different cells including Schwann cells [48]. IGF1 is a strong inhibitor of apoptosis also in Schwann cells $[49,50]$ and promotes Schwann cell motility [51]. But, IGFP-1 also exerts IGF-independent effects on cell growth, differentiation and survival [52]. IGFBP-2 correlates with tumour grade in gliomas [47]. IGFBP-1 has found to be expressed in astrocytomas and meningiomas [53]. Increased IGFBP1 levels seem to be associated with endometrial cancer risk in older women and women with a higher body mass index [54]. The same authors also found a positive association of IGFBP-1 and ovarian cancer [55].

The expression of the gene for tyrosine kinase with immunoglobulin and EGF factor homology domains (TIE1) was reduced in schwannoma cells. This is the first time that TIE 1 is described in Schwann cells. This endothelial surface receptor with kinase activity is involved in vascular development and probably in cell adhesion to the vascular endothelium. It has been found to be over expressed in various cancers, where it was shown to activate Akt via PI3-kinase to inhibit apoptosis [56]. This role 
could be true in schwannoma as well as we recently described reduced apoptosis rates in primary human schwannoma cells [57].

Tyrosine kinase, nonreceptor 1 (TNK1) is upregulated in schwannoma cells, this being the first description of TNK1 in Schwann cells. TNK1 was first identified in haematopoietic stem cells and binds to phospholipase Cgamma 1, suggesting a role in phospholipid signal transduction [58]. Beside this, little is yet known about this protein.

Regarding the MAP kinase pathways in Schwann cells most papers deal with the MEK1/2 Erk1/2 pathway, while MEK3 has not been studied in Schwann cells. However, inhibition of p38 MAP-kinase downstream of MEK3 results in reduced apoptosis of Schwann cells in vivo [59] and decreased myelination [60], suggesting that the MEK3/p38 pathway could be relevant in schwannomas.

Holtkamp et al. 2004 [61] investigated the differential gene expression of other tumours originating from peripheral nerves, such as benign dermal and plexiform neurofibromas and malignant peripheral nerve sheath tumours (MPNST) of neurofibromatosis type 1 (NF1) patients. Dermal neurofibromas originate from Schwann cells affected by a second hit in the tumour suppressor gene NF1, and MPNSTs originate from plexiform neurofibromas, thereby presenting an interesting model of tumour progression. They found clear differences in gene expression between all three tumour types, being most prominent when comparing dermal neurofibromas and MPNSTs. Two of the genes differentially expressed in those tumours were also identified by us in the study of Schwann and NF2 schwannoma cells. Integrin $\alpha 6$ (ITGA6) and prion protein (PRNP) are highly expressed in dermal neurofibromas, but downregulated in MPNSTs, expression in plexiform neurofibromas being in between. Unfortunately, Holtkamp et al. did not compare the tumour samples to normal controls, so the basal expression level of ITGA6 and PRNP is unknown.

Differentially regulated genes and genes not previously known to be expressed by Schwann cells identified in the here presented study certainly need to be investigated in greater detail, including protein expression levels, kinase activities and analysis of the functional relevance in suitable read outs. This work is currently under way in our group. However, detailed biochemical assays in the in vitro model of human Schwann and schwannoma cells, is difficult due to limited access to biopsy material. Moreover primary human Schwann and schwannoma cell cultures show a limited lifespan of 5-6 weeks. Even though realtime PCR is a far more sensitive method than cDNA array hybridization, even here the low amount of RNA available led to a higher variation than expected. A similarly sensitive method for the measurement of protein amounts is not yet available. However, it is important to note that the validity of our model has been proved by following-up on the integrin expression data [9], indicating a role for Rac1 in schwannoma [19], and by showing corresponding protein expression levels of RhoGDI and p75 protein in this paper.

In conclusion, we have identified a number of novel candidate genes with differential regulation in primary human Schwann and schwannoma cells, some of which were yet not known to be expressed by Schwann cells. Further studies will have to show their relevance for schwannoma formation.

\section{References}

1 Rouleau GA, Merel P, Lutchman M, Sanson M, Zucman J, Marineau C, Hoang-Xuan K, Demczuk S, Desmaze C, Plougastel $\mathrm{B}$. Alteration in a new gene encoding a putative membrane organizing protein causes neurofibromatosis type 2. Nature 1993; 363: 515-21

2 Trofatter JA, MacCollin MM, Rutter JL, Murrell JR, Duyao MP, Parry DM, Eldridge R, Kley N, Menon AG, Pulaski K. A novel moesin-, ezrin-, radixin-like gene is a candidate for the neurofibromatosis 2 tumor suppressor (published erratum appears in Cell 1993 November 19; 75(4): 826). Cell 1993; 72: 791-800

3 Ferner RE, O'Doherty MJ. Neurofibroma and schwannoma. Curr Opin Neurol 2002; 15: 679-84

4 Gutmann DH. The neurofibromatoses: when less is more. Hum Mol Genet 2001; 10: 747-55

5 Wolff RK, Frazer KA, Jackler RK, Lanser MJ, Pitts LH, Cox DR. Analysis of chromosome 22 deletions in neurofibromatosis type 2-related tumors. Am J Human Genet 1992; 51: 478-85

6 Sainz J, Huynh DP, Figueroa K, Ragge NK, Baser ME, Pulst SM. Mutations of the neurofibromatosis type 2 gene and lack of the gene product in vestibular schwannomas. Human Mol Genet 1994; 3: 885-91

7 Kimura Y, Saya H, Nakao M. Calpain-dependent proteolysis of NF2 protein: involvement in schwannomas and meningiomas.[In Process Citation]. Neuropathology 2000; 20: 153-60

8 Lallemand D, Curto M, Saotome I, Giovannini M, McClatchey AI. NF2 deficiency promotes tumorigenesis and metastasis by destabilizing adherens junctions. Genes Dev 2003; 17: 1090-100

9 Utermark T, Kaempchen K, Hanemann CO. Pathological adhesion of primary human schwannoma cells is depen- 
dent on altered expression of integrins. Brain Pathol 2003; 13: 352-63

10 McClatchey AI, Saotome I, Mercer K, Crowley D, Gusella JF, Bronson RT, Jacks T. Mice heterozygous for a mutation at the Nf2 tumor suppressor locus develop a range of highly metastatic tumors. Genes Dev 1998; 12: 1121-33

11 Scoles DR, Huynh DP, Morcos PA, Coulsell ER, Robinson NG, Tamanoi F, Pulst SM. Neurofibromatosis 2 tumour suppressor schwannomin interacts with betaII-spectrin. Nature Genet 1998; 18: 354-9

12 Sainio M, Zhao F, Heiska L, Turunen O, den Bakker M, Zwarthoff E, Lutchman M, Rouleau GA, Jaaskelainen J, Vaheri A, Carpen O. Neurofibromatosis 2 tumor suppressor protein colocalizes with ezrin and CD44 and associates with actin-containing cytoskeleton. J Cell Sci 1997; 110: 2249-60

13 Wiederhold T, Lee MF, James M, Neujahr R, Smith N, Murthy A, Hartwig J, Gusella JF, Ramesh V. Magicin, a novel cytoskeletal protein associates with the NF2 tumor suppressor merlin and Grb2. Oncogene 2004; 23: 881525

14 Scoles DR, Nguyen VD, Qin Y, Sun CX, Morrison H, Gutmann DH, Pulst SM. Neurofibromatosis 2 (NF2) tumor suppressor schwannomin and its interacting protein HRS regulate STAT signaling. Hum Mol Genet 2002; 11: 3179-89

15 Fernandez-Valle C, Tang Y, Ricard J, Rodenas-Ruano A, Taylor A, Hackler E, Biggerstaff J, Iacovelli J. Paxillin binds schwannomin and regulates its density-dependent localization and effect on cell morphology. Nat Genet 2002; 31: 354-62

16 Murthy A, Gonzalez-Agosti C, Cordero E, Pinney D, Candia C, Solomon F, Gusella J, Ramesh V. NHE-RF, a regulatory cofactor for $\mathrm{Na}(+)-\mathrm{H}+$ exchange, is a common interactor for merlin and ERM (MERM) proteins. J Biol Chem 1998; 273: 1273-6

17 Rong R, Tang X, Gutmann DH, Ye K. Neurofibromatosis 2 (NF2) tumor suppressor merlin inhibits phosphatidylinositol 3-kinase through binding to PIKE-L. Proc Natl Acad Sci USA 2004; 101: 18200-5

18 Kissil JL, Johnson KC, Eckman MS, Jacks T. Merlin Phosphorylation by p21-activated Kinase 2 and Effects of Phosphorylation on Merlin Localization. J Biol Chem 2002; 277: 10394-9

19 Kaempchen K, Mielke K, Utermark T, Langmesser S, Hanemann CO. Upregulation of the Rac1/JNK signaling pathway in primary human schwannoma cells. Hum Mol Genet 2003; 12: 1211-21

20 Kissil JL, Wilker EW, Johnson KC, Eckman MS, Yaffe MB, Jacks T. Merlin, the product of the Nf2 tumor suppressor gene, is an inhibitor of the p21-activated kinase, Pak1. Mol Cell 2003; 12: 841-9

21 Hirokawa Y, Tikoo A, Huynh J, Utermark T, Hanemann CO, Giovannini M, Xiao GH, Testa JR, Wood J, Maruta H. A clue to the therapy of neurofibromatosis type 2: NF2/ merlin is a PAK1 inhibitor. Cancer J 2004; 10: 20-6
22 Rong R, Surace EI, Haipek CA, Gutmann DH, YeK. Serine 518 phosphorylation modulates merlin intramolecular association and binding to critical effectors important for NF2 growth suppression. Oncogene 2004; 23: 8447-54

23 Shaw RJ, Paez JG, Curto M, Yaktine A, Pruitt WM, Saotome I, O’Bryan JP, Gupta V, Der Ratner NCJ, Jacks T, McClatchey AI. The Nf2 tumor suppressor, merlin, functions in Rac-dependent signaling. Dev Cell 2001; 1: 6372

24 Kim H, Kwak NJ, Lee JY, Choi BH, Lim Y, Ko YJ, Kim YH, Huh PW, Lee KH, Rha HK, Wang YP. Merlin neutralizes the inhibitory effect of Mdm2 on p53. J Biol Chem 2004; 279: 7812-18

25 Hanemann CO, Rosenbaum C, Kupfer S, Wosch S, Stoegbauer F, Mueller HW. Improved culture methods to expand Schwann cells with altered growth behaviour from CMT1A patients. GLIA 1998; 23: 89-98

26 Rosenbaum C, Kluwe L, Mautner VF, Friedrich RE, Mueller HW, Hanemann CO. Isolation and characterization of Schwann cells from neurofibromatosis type 2 patients. Neurobiol Dis 1998; 5: 55-64

27 The Consensus Development Panel. National Institutes of Health Consensus Development Conference Statement on Acoustic Neuroma, December 11-13, 1991. Arch Neurol 1994; 51: 201-7

28 Chomczynski P, Sacchi N. Single-step method of RNA isolation by acid guanidinium thiocyanate-phenolchloroform extraction. Anal Biochem 1987; 162: 156-9

29 Ramakers C, Ruijter JM, Deprez RH, Moorman AF. Assumption-free analysis of quantitative real-time polymerase chain reaction (PCR) data. Neurosci Lett 2003; 339: 62-6

30 Vandesompele J, De Preter K, Pattyn F, Poppe B, Van Roy N, De Paepe A, Speleman F. Accurate normalization of real-time quantitative RT-PCR data by geometric averaging of multiple internal control genes. Genome Biol 2002; 3: RESEARCH0034

31 Sherman L, Jacoby LB, Lampe J, Pelton P, Aguzzi A, Herrlich P, Ponta H. CD44 expression is aberrant in benign Schwann cell tumors possessing mutations in the neurofibromatosis type 2, but not type 1 , gene. Cancer Res 1997; 57: 4889-97

32 Utermark T, Schubert SJ, Hanemann CO. Rearrangements of the intermediate filament GFAP in primary human schwannoma cells. Neurobiol Dis 2005; 19: 1-9

33 Yamauchi J, Chan JR, Shooter EM. Neurotrophins regulate Schwann cell migration by activating divergent signaling pathways dependent on Rho GTPases. Proc Natl Acad Sci USA 2004; 101: 8774-9

34 Welling DB, Lasak JM, Akhmametyeva E, Ghaheri B, Chang LS. cDNA microarray analysis of vestibular schwannomas. Otol Neurotol 2002; 23: 736-48

35 Toda K, Small JA, Goda S, Quarles RH. Biochemical and cellular properties of three immortalized Schwann cell lines expressing different levels of the myelin-associated glycoprotein. J Neurochem 1994; 63: 1646-57 
36 Rosenbaum C, Kamleiter M, Grafe P, Kluwe L, Mautner V, Muller HW, Hanemann CO. Enhanced proliferation and potassium conductance of Schwann cells isolated from NF2 schwannomas can be reduced by quinidine. Neurobiol Dis 2000; 7: 483-91

37 Ford MJ, Burton LJ, Morris RJ, Hall SM. Selective expression of prion protein in peripheral tissues of the adult mouse. Neuroscience 2002; 113: 177-92

38 Diarra-Mehrpour M, Arrabal S, Jalil A, Pinson X, Gaudin C, Pietu G, Pitaval A, Ripoche H, Eloit M, Dormont D, Chouaib S. Prion protein prevents human breast carcinoma cell line from tumor necrosis factor alpha-induced cell death. Cancer Res 2004; 64: 719-27

39 Hartung HP, Kieseier BC. The role of matrix metalloproteinases in autoimmune damage to the central and peripheral nervous system. J Neuroimmunol 2000; 107: 140-7

40 Muir D. Differences in proliferation and invasion by normal, transformed and NF1 Schwann cell cultures are influenced by matrix metalloproteinase expression. Clin Exp Metastasis 1995; 13: 303-14

41 Ito Y, Yamamoto M, Li M, Mitsuma N, Tanaka F, Doyu M, Suzumura A, Mitsuma T, Sobue G. Temporal expression of mRNAs for neuropoietic cytokines, interleukin-11 (IL11), oncostatin M (OSM), cardiotrophin-1 (CT-1) and their receptors (IL-11Ralpha and OSMRbeta) in peripheral nerve injury. Neurochem Res 2000; 25: 1113-18

42 Tjwa M, Luttun A, Autiero M, Carmeliet P. VEGF and PlGF: two pleiotropic growth factors with distinct roles in development and homeostasis. Cell Tissue Res 2003; 314: 5-14

43 Mukouyama YS, Gerber HP, Ferrara N, Gu C, Anderson DJ. Peripheral nerve-derived VEGF promotes arterial differentiation via neuropilin 1-mediated positive feedback. Development 2005; 132: 941-52

44 Sondell M, Lundborg G, Kanje M. Vascular endothelial growth factor has neurotrophic activity and stimulates axonal outgrowth, enhancing cell survival and Schwann cell proliferation in the peripheral nervous system. J Neurosci 1999; 19: 5731-40

45 Gollmer JC, Ladoux A, Gioanni J, Paquis P, Dubreuil A, Chatel M, Frelin C. Expression of vascular endothelial growth factor-b in human astrocytoma. Neuro-Oncol 2000; 2: 80-6

46 Caye-Thomasen P, Werther K, Nalla A, Bog-Hansen TC, Nielsen HJ, Stangerup SE, Thomsen J. VEGF and VEGF receptor-1 concentration in vestibular schwannoma homogenates correlates to tumor growth rate. Otol Neurotol 2005; 26: 98-101

47 Pollak MN, Schernhammer ES, Hankinson SE. Insulinlike growth factors and neoplasia. Nat Rev Cancer 2004; 4: 505-18

48 Cheng HL, Randolph A, Yee D, Delafontaine P, Tennekoon G, Feldman EL. Characterization of insulin-like growth factor-I and its receptor and binding proteins in transected nerves and cultured Schwann cells. J Neurochem 1996; 66: 525-36

49 Delaney CL, Cheng HL, Feldman EL. Insulin-like growth factor-I prevents caspase-mediated apoptosis in Schwann cells. J Neurobiol 1999; 41: 540-8

50 Furstenberger G, Senn HJ. Insulin-like growth factors and cancer. Lancet Oncol 2002; 3: 298-302

51 Cheng HL, Steinway ML, Russell JW, Feldman EL. GTPases and phosphatidylinositol 3-kinase are critical for insulin-like growth factor-I-mediated Schwann cell motility. J Biol Chem 2000; 275: 27197-204

52 Ricort JM. Insulin-like growth factor binding protein (IGFBP) signalling. Growth Horm IGF Res 2004; 14: 27786

53 Zumkeller W, Westphal M. The IGF/IGFBP system in CNS malignancy. Mol Pathol 2001; 54: 227-9

54 Augustin LS, Dal Maso L, Franceschi S, Talamini R, Kendall CW, Jenkins DJ, Vidgen E, La Vecchia C. Association between components of the insulin-like growth factor system and endometrial cancer risk. Oncology 2004; 67 : 54-9

55 Dal Maso L, Augustin LS, Franceschi S, Talamini R, Polesel J, Kendall CW, Jenkins DJ, Vidgen E, La Vecchia C. Association between components of the insulin-like growth factor system and epithelial ovarian cancer risk. Oncology 2004; 67: 225-30

56 Kontos CD, Cha EH, York JD, Peters KG. The endothelial receptor tyrosine kinase Tie1 activates phosphatidylinositol 3-kinase and Akt to inhibit apoptosis. Mol Cell Biol 2002; 22: 1704-13

57 Utermark T, Kaempchen K, Antoniadis G, Hanemann CO. Reduced apoptosis rates in human schwannomas. Brain Pathol 2005; 15: 17-22

58 Felschow DM, Civin CI, Hoehn GT. Characterization of the tyrosine kinase Tnk1 and its binding with phospholipase C-gamma1. Biochem Biophys Res Commun 2000; 273: 294-301

59 Myers RR, Sekiguchi Y, Kikuchi S, Scott B, Medicherla S, Protter A, Campana WM. Inhibition of p38 MAP kinase activity enhances axonal regeneration. Exp Neurol 2003; 184: 606-14

60 Fragoso G, Robertson J, Athlan E, Tam E, Almazan G, Mushynski WE. Inhibition of p38 mitogen-activated protein kinase interferes with cell shape changes and gene expression associated with Schwann cell myelination. Exp Neurol 2003; 183: 34-46

61 Holtkamp N, Reuss DE, Atallah I, Kuban RJ, Hartmann C, Mautner VF, Frahm S, Friedrich RE, Algermissen B, Pham VA, Prietz S, Rosenbaum T, Estevez-Schwarz L, von Deimling A. Subclassification of nerve sheath tumors by gene expression profiling. Brain Pathol 2004; 14: 258-64 